\title{
Ruci's Joint Marketing Public Relations Strategy in Conducting and Communicating Rebranding to Increase Sales Value
}

\author{
Theresia Sharron Sanjaya \\ London School of Public Realtions Jakarta, Indonesia \\ Email: sharron.sanjaya1809@gmail.com
}

\begin{tabular}{|c|c|}
\hline ARTICLE INFO & ABSTRACT \\
\hline $\begin{array}{l}\text { Date Received: } 12 \\
\text { November } 2020 \\
\text { Revision Date : } 15 \\
\text { December } 2020 \\
\text { Date Received : } 04 \\
\text { January } 2021 \\
\end{array}$ & $\begin{array}{l}\text { This research is expected to provide clearer explanations to readers regarding } \\
\text { the Strategy of Marketing Public Relations Ruci's Joint conducting and } \\
\text { communicating rebranding to increase sales value. The purpose of this } \\
\text { research is to know Marketing Public Relations Ruci's Joint's Strategy in } \\
\text { conducting and communicationg rebranding to increase sales value. The main } \\
\text { theory used is Marketing Public Relations and the other supporting theories are }\end{array}$ \\
\hline $\begin{array}{l}\text { Keywords: } \\
\text { Rebranding; } \\
\text { Food and beverage; } \\
\text { Cafe; } \\
\text { Sales; }\end{array}$ & $\begin{array}{l}\text { brand, and rebranding. The method of insulation used is a qualitative } \\
\text { descriptive method. Data collection thechniques are done by conducting in- } \\
\text { depth interviews, and observations. The speakers in this study are form internal } \\
\text { and external companies. The data obtained from the subject of this study are } \\
\text { analyzed by data analysis techniques, while for the data trust techniques using } \\
\text { source triangulation data. }\end{array}$ \\
\hline
\end{tabular}

Coresponden Author:

Email: sharron.sanjaya1809@gmail.com Article with open access under license

\section{INTRODUCTION}

In the world of business, it is necessary to plan a or more strategies and timelines that help achieve the vision and mission of the company. Marketing Public Relations is tasked with creating strategies and timelines to educate consumers to increase the value of sales for the company. Public Relations and marketing are very related, although they have different roles. As quoted in a journal entitled Journal in Consumer Behaviour in 2014 "The term Marketing Public Relations was coined in the 1980s in an effort to distinguish the use of public relations techniques in achieving marketing objectives from the general practice of public relations" (Harris \& Whalen, 2006). PR and marketing have a supporting role. PR functions in raising the image of the company, while marketing is more focused on sales.

Strategies that can be made start from social media. Social media is used to maintain the company's relationship with the public, starting with creating content, captions, hashtags that affect the content that has been created. The food and beverage industry can also cooperate with related online applications to raise company names, such as Zomato, Qraved, Gojek, Grab and others. Doing promotions is one of the strategies and such promotions can be used as content from the social media of the restaurant itself. In addition, create internal events by working with other event organizers as well as external events from outside parties who want to cooperate with our company. The author wants to focus on the rebranding strategy, because rebranding can be used as the right strategy for this restaurant.

Solika in his research said that rebranding is an effort made by the company to completely change or renew an existing brand, without neglecting the company's original goal of profitoriented. Rebranding as a brand change, often synonymous with logo change, in other words, when rebranding then what changes is the values in the brand itself. Brand changes concern changes in logos, names, perceptions, marketing strategies, or advertising themes.

Solika also said that the general purpose of rebranding is to influence consumer perception of a product or service by revitalizing the brand and making it more modern and more relevant to the needs of consumers so as to make them interested in the company's products.

The benefits of branding are not just the design of a company logo. Branding is a relationship between consumers and companies, between consumers and products. Branding should be designed as best as possible to give a positive impression to its consumers (Budi, 2010).

Dunia Food and Beverage or often also called F\&amp;B sells food and beverage products, and not only that, in the world of F\&amp;B service, places and locations are very important to note, because the combination of these four things is 
what can improve the name of their restaurant so that it affects the level of sales. Even nowadays people who do business in the world of cafes or restaurants they make the concept in such a way 

that the visitors are comfortable and want to visit again. Nowadays, the world of food and beverage is very developed rapidly and of course has a very wide market of various circles can become customers depending on the type of restaurant or café. Not only regular customers, restaurants or cafes can also be used as a place to hold various events both internally and externally. According to statistical data from Q2 2017, the Central Statistics Agency (BPS) Report has stated that in 2017 the food and beverage trade industry has increased by 5.07\% (Q2 2017 Badan Pusat Statistik (BPS ) Report, n.d.) (Source: Indonesia's economic growth in the second quarter of 2017).

Liputan6.com, Jakarta - Chairman of the Indonesian Food and Beverage Association (GAPMMMI), January 30, 2018 The food and beverage industry has the potential to grow by more than $10 \%$ in 2018 . The growth is supported by the moment of regional head elections (regional elections) so that the circulation of money increases. "The food and beverage industry also contributed $6.21 \%$ to national GDP in the third quartile of 2017 , an increase of $3.85 \%$ compared to the same period last year." (Lukman, 30 January 2018)

The restaurant business deals with planning and prediction as well as competition. It is inevitable that all businesses, especially businesses in the world of food and beverage are related to pressures, many conditions that need to be considered, one of which is when restaurants are too crowded or too quiet to be a problem for people who do business in the world of food and beverage. Restaurants are scattered everywhere, there are many forms, styles, scales, types of cuisine, and nuaansa kesukannya various. (Torisna, 2010, p. 2)

The café that the author wants to research is Ruci's Joint. Ruci's Joint is a restaurant that can be called café and bar located at Jalan Suryo Blok S No. 49, Rawa Barat, Kebayoran Baru. Ruci's Joint is a subsidiary of PT. Ruci's Art Partner. The company also has an art gallery located in the same building Ruci's Joint concept art cafe bar where there are interiors that have artistic value, even sometimes they sell souvenirs that have artistic value in their café. Ruci's Joint owns social media such as Instagram with more than 3000 followers, and is the manager of various online applications such as Zomato and Qraved. Ruci's Joint also collaborates with Provoke Youth Club media (Source: Julius Wisnu, Personal Communication, June 2, 2019).

Various strategies and ways of promotion are carried out to attract customers so that the sales value of the restaurant or café can increase. One of the strategies used by Ruci's Joint and the author will discuss is the rebranding strategy that has been carried out by Ruci's Joint. Initially Ruci's Joint shaped like a food court consisted of many booths in collaboration with several food and beverage brands such as Tuku, Burgushi, Ya dong Dimsum, and Frux. In December 2017, Ruci's Joint rebranded by changing the logo, concept and image of Ruci's Joint itself, which started from a food court-like shape to the present day in the form of restaurants, cafes, and bars.

Not many food industries are rebranding by changing the concept to such extremes. There are some restaurants that rebrand just to change the logo and menu, such as Hokben, Pizza Hut, and others. Although Ruci's Joint rebranded, Ruci's Joint only changed the concept, logo, and imagery of the place, but did not rename it. In contrast to Ruci's Joint which rebranded based on the commitment of the brands that cooperated with Ruci's Joint so that the concept was changed to one.

Ruci's Joint also provides a place to rent as an internal and external event. Usually if the external event is usually called function, where the client or company that rents will hold press conference, product launching, talk show and others. If the internal event is more like karaoke together, watch together, movie screening, and others. The events are planned and applied by Marketing Public Relations of Ruci's Joint to increase the level of sales value and raise the name of Ruci's Joint in accordance with the objectives of the company.

In general, restaurants create internal events that aim to introduce their names widely and certainly increase the value of their sales. Such as regular live music events, regular DJs, events every month as well as certain promotions that have been planned. There are also those who hold external events but different concepts in the sense, event organizers from outside the company who want to hold an event in the restaurant or can be called a function. Of course, the purpose is different, if the event from the outside is usually closed to the public, the purpose of the restaurant is to focus on the advantages of the restaurant.

Of the many cafes, writers are attracted to Ruci's Joint because of the quality they have and the imagery that Ruci's Joint has. Their strategies are also different from others. They work with one of the event organizers, HENZZLE, to create regular events, usually once a month. Events are held like karaoke. So far, the event created by Ruci's Joint has managed to increase their sales value by inviting several hosts as singers to enliven the event. Therefore the author is interested in researching Ruci's Joint.

The author is very interested to research about the world of Food and Beverages because nowadays the industrial world is growing, can be seen in the street senopati hamnpir entirely a restaurant. There is no denying that everyone needs to eat and drink, both of which are one of the primary needs of human beings. Therefore, it is necessary to note the quality of food and drinks of a 
restaurant. If the quality is good and in accordance with market tastes, consumers will continue to come. The strategy of restaurants to be able to continue to grow and be able to compete with their competitors so as to maintain customer loyalty.

The author also wanted to find out if Ruci's Joint Marketing Public Relations was successful in changing the image, concept, logo, of Ruci's Joint itself. Because it can be seen the rebranding that has been done Ruci's Joint is quite significant, which was in the form of a food court so that it becomes a restaurant and art café. Is it effective after the rebranding and what needs to be developed again in order to maintain customer loyalty from Ruci's Joint. The author wants to know if the rebranding strategy is successful, whether this strategy needs to be done for other restaurants in order to maintain customer loyalty.

As a practitioner of Public Relations, especially Marketing Public Relations in the world of F\&amp;B, of course, must know how to set the strategy and make the timeline do not let there be a decrease in sales value. Including the use of social media, ruci's joint may not have a lot of social media, but without a doubt social media is very influential for a product because nowadays social media is one form of portfolio for a person as well as a product. Therefore, the author wanted to raise the title of research on "Ruci's Joint Marketing Public Relations Strategy in Conducting and Communicating Rebranding to Increase Sales Value".

\section{Marketing Public Relations}

Emergence of Marketing Public Relations since the 1930s in America. Edward Bernarys, the father of modern public relations, successfully created various Marketing Public Relations programs. He uses communication tools commonly used by public relations, namely article writing and third-person endorser as a persuasive way to bring products closer to consumers (Thomas L. Harris, 1993 P. 13).

Public Relations conducts publications that become a sub-part of the marketing function to promote products to the public, especially their target market. Public Relations and marketing can not be separated from each other the desired results of a public relations company can do marketing more effectively. (Haliza, Kailaku, \& Yuliani, 2017) (Sari, 2007 p. 45)

According to Rhenal Kasali, the audience of Marketing Public Relations is the community and consumers, therefore it can be interpreted that Marketing Public relations is as the management of communication to motivate the purchase and satisfaction of customers, consumers, and the public. Marketing Public Relations brings two ways communications traffic closer between brands and communities. (Ali, 2017).
The concept gave birth to the theory of three ways strategy to create public opinion so as to create an image of the company itself. Here's an explanation of the three ways strategy:

1. Push Strategy

Promotional strategies used by marketers to get the brand or product it manages to customers. The strategy is to sell goods directly to customers. Utilizing sales force to sell its products directly and can get incentives if the sales target is achieved. This strategy is effectively used for new brands that do not yet have a high enough value of the product or the brand itself. So sales force is entrusted to educate end customers directly about the products and brands of the company itself..

2. Pull Strategy

The purpose of pull marketing is to get customers to visit the brand. Common sales strategies include promotion through masaa media, directional word of mouth, and sales through advertising. In terms of business, pull marketing is an effort to create brand loyalty and make customers dating back while push marketing is more aimed at short-term sales.

3. Power Strategy (Pass Strategy)

Public relations has the power to influence and create public opinion about a company. This strategy is used to persuade the public to potentially support the achievement of marketing public relations goals. Pass- strategy is a strategy carried out by marketing public relations to conduct the same with various companies or other organizations. It can be in the form of sponsorship, partnership, or holding an event. (Salmiyah, 2017, p. 47).

4. Worth of Mouth

Marketing activities known as 4P or new marketing (product, price, place, promotion) that must be managed to meet the needs of consumers without oversleping the company's objectives. Promotions are used to inform, introduce and remind people about products and to improve the target market of distribution channels and the public to purchase a company's products (Factors that make up Word of Mouth communication and its effect on Purchasing Decisions, 2013)

Fridgen in Susanto (2002:6) states that promotional instruments consist of personal selling, advertising publicity, public relations, worf of mouth, and sales promotion. Based on research conducted by Onbee Marketing Research in collaboration with SWA magazine (2009) proved that the level of WOM Conversation (retelle to others) is $85 \%$ and makes WOM as a source of information to change its decision by $67 \%$.

WOM itself literally has the sense of word of mouth marketing, usually starting from 
something natural and unplanned. Puspito in Fahima (2008) explained that the most basic thing in the creation of WOM, is when the product can give satisfaction to its customers. WOM is very concerned with the customer experience of a product from the company.

Film As a Brand Brand is very important for a company. John Stuart, CEO of Quaker Oats from 1922 to 1956 quoted by Christina Ariadne Sekar Sari in the book Product and Brand Managing Techniques said that "if this company were to split up I would give you the property, plant, and equipment and I would take the brands and the trademarks and I would fare better than you." Every company needs to pay attention to the role of the brand. Good brand management needs to be done to increase the brand equity of a brand. (Sari, 2017)

According to the American Marketing Association (AMA), a brand is a name, term, mark, symbol, or design, or a combination of all of them, intended to identify the goods and services of a seller or group of sellers and to differentiate them from competition. Brands not only talk about names and logos, but one organization's commitment to customers to deliver what is already the brand's principle. (Sari, 2017)

The key to creating a brand, based on the AMA's definition, is the ability of manufacturers to select brand elements, so that consumers can identify products and differentiate from other manufacturers. Brand elements are different components of the brand, which identify and distinguish them from other manufacturers namely, name, logo, symbol, packaging design, and other characteristics.(Sari, 2017)

\section{Rebranding}

The word rebranding has the meaning and intent of rebranding. According to Muzellec and Lambkin (2006) as quoted by previous researchers by Muhammad Izharuddin with the title Rebranding Process at Plasa Marina Using Complex Process Model revealed that the word "rebrand" is a new word formation, consisting of two words 're' and 'brand'. Re is the prestate for a verb, which can mean "again" or "new", squandering that action is performed at another time. Therefore, according to Muzellec and Lambkin (2006) the proper understanding of rebranding is to create a new name, term, symbol, design, or a combination of all for one brand that is undeniable with the aim of developing differentiation (new) positions in the minds of stakeholders and competitors.

Rebranding is more than just changing the brand name. Rebranding requires a lot of research and cost. A company can not easily change the concept or brand of the company, it is necessary to apply research and plan strategies to rebrand so that the purpose of the company is achieved. In most cases of rebranding, companies change their names in order to change the concept and develop the products and companies they own..

\section{METHOD}

The research method that researchers use is qualitative with interpretative approach. In the research methodology book by $V$. Wiratna Surwajeweni in 2014 quoting Strauss and Corbin (1997) revealed that qualitative research is a type of research that produces discoveries that cannot be achieved (obtained) by using statistical procedures or other means of quantification (measurement).

Qualitative research is generally used for research on people's lives, history, behavior, organizational functionation, social activities, and others. The understanding of interpretative itself according to kbbi dictionary is the existence of messages, opinions, and views; related to the interpretation. Researchers use descriptive qualitative methods with interpretative approach with the intention of obtaining interpretation of strategies carried out by Marketing Public Relations Ruci's Joint when rebranding.

The data obtained from qualitative research is descriptive. In the form of speech or writing from things that researchers observe in a certain state of context that is examined from a whole, comprehensive, and holistic point of view. This research includes action research which means the research is aimed at finding effective methods in the daily activities of the company. This research is a process of individuals or groups who want change so that they can get accountable conclusions. (Sujarweni, 2014).

\section{RESULT AND DISCUSSION}

Overall of the rebranding process that took place both pre, due, and post rebranding that occurred, the strategy used by Ruci's Joint was very effective and successful. And now Ruci's Joint has been running in accordance with the vision and mission of Ruci's Joint at first. Indeed Ruci's Joint did not change its name, but the logo and concept of Ruci's Joint changed drastically. In terms of consumers, koknsumen prefer Ruci's Joint which is currently. The facilities provided from Ruci's Joint are now very varied as previously written. Not only sell food and beverages but Ruci's Joint is also willing if there are external customers who want to make an event in Ruci's joint until Ruci's Joint has to close its business on that day.

The concept of business made is very varied. Shareholders and staff are also pleased with the successful rebranding of Ruci's Joint. Not many restaurants are rebranding by changing the sedrastis that Ruci's Joint does. Ruci's Joint was brave enough to take a risk when it decided to rebrand. 
"I can not answer the details yes. But for traffic we are quite far, far away yes maybe at the figure of $80 \%$ but for the same income can reach the estimated 80 to 90 cents after rebranding." (Julius Wisnu, interview July 4, 2019).

Mr Julis Wisnu has said that the srtegi that has been implemented for the rebranding of Ruci's Joint has been very successful even increasing the value of sales by about $80 \%$ from before.

From the consumer side of each consumer source who interviewed researchers, they prefer ruci's joint which is now, both in terms of practical when paying, in terms of convenience, and in terms of events that have been designed by Ruci's Joint itself

"The place is more neat. So yes it's good now. But if the old tuh there tuku. But now Ruci also has his own iced milk coffee." (Mutiara, interview July 4, 2019)

"prefer Ruci's Joint which is now for sure. The menu is more if it used to be really limited tuh menu for nasi goring aja tuh cuman there are only 3 coffees there are 1 and 2 types are quite complicated because the pay is a lot of cashiers. There are four cashiers. If now everything is ydah under him become easier." (Dhany Indra, interview July 4, 2019)

The events created by Ruci's Joint both in cooperation with internal and external parties indirectly give rise to the nature of loyalty for consumers. The public is much more familiar with Ruci's Joint with brand image which is full of credibility and art. In terms of traffic is not as fast as it used to be because nowadays people who come to Ruci's Joint aim to work mupun gather with friends, but it is not a bad thing because it is in accordance with the purpose of the owner of Ruci's Joint, Mr. Tomy Sibarani.

In terms of strategy, Ruci's Joint has been quite effective and does not cost much for its communication. Communication is done only through social media, especially Instagram and WOM which is very reliable by Mr. Julius Wisnu. WOM is the most influential of the successful rebranding of Ruci's Joint itself. Ruci's Joint also has a strategy to benefit people who have high folowers on his instagram to be one of the Hosts to come to the event that has been created Ruci's Joint. Indirectly, the person will post on his instagram and introduce Ruci's Joint.

This research uses interview techniques and data triangulation. Based on the interviews of the four sources, the source gave approximately the same answer. In the internal sense, internal sources say that transactions and traffic are very much increased in comparison before rebranding even up to more than $80 \%$. The current condition of Ruci's Joint is in accordance with the vision and mission of the company (Ruci's Joint). Before the rebranding of Ruci's Joint image was very different from the current one. In the past, Ruci's Joint was very visited by Gojek to buy TUKU coffee drinks, in other words Ruci's Joint has an image of where to buy TUKU. While Ruci's Joint is actually made to support pt. OTHER RUCI ART PARTNERS (Ruci's Art Gallery).

\section{CONCLUSION}

Rebranding conducted by marketing public relations division of Ruci's Joint aka General Manager of Ruci's Joint under pt. RUCI Art Partners has used elements of the staging rebranding process, starting from Ruci's Joint public relations marketing strategy in determining the hierarchy of rebranding, the rebranding format. All had been planned and as a result Ruci's Joint did not change their name, but they changed the concept of its overall sales strategy and changed the menus of their products.

Marketing Public Relations Ruci's Joint conveys a message through Lasswell's theory, namely Who, Says What, In What Channel, To Whom, In What Effect. The application of these elements by Ruci's Joint to customers and internal staff has also taken place in accordance with the timeplan that has been made by the General Manager of Ruci's Joint itself. Based on all the results of researchers' interviews with customers, the source said that they were more satisfied and had a better customer journey after Ruci's Joint rebranded. In terms of sales value, Mr. Tommy Sibarani and Mr. Julius Wisnu said that the value of their sales after rebranding is much higher than before rebranding. Not only in terms of sales value, but in terms of traffic, Ruci's Joint is quite crowded. Mutiara's source also said the same thing, he said that currently Ruci's Joint has a lot of customers even sometimes have to make reservations and when other customers can not then they can not visit Ruci's Joint. In terms of strategy that has been diguankan by Ruci's Joint does not have much cost in terms of its promotion. The strategy used and the Timeplan that has been prepared from GM Ruci's Joint is very effective and smooth so it has an excellent impact for Ruci's Joint.

\section{REFERENCES}

Ardianto, E, Soemirat. S. (2007). Dasar-Dasar Public Relations. Bandung: PT Remaja Rosdakarya.

Aotama, F.F. Marketing Public Relations, 2-3. Diakses dari Blog https://www.academia.edu/9 417636/Marketing_Public_Relations?auto=dow nload

Asep Saepul Hamdi E. Bahruddin. (2014) Metode Penelitian Kuantitatif Aplikasi dalam Pendidikan. Yogyakarta CV Budi Utama 
Bagus, D. (2010). Konsep Marketing Public Relations (MPR): Definisi dan Peran Marketing Public Relations. Diakses dari Blog http://jurnal sdm.blogspot.com/2009/08/konsep -marketing-public-relations-mpr.html

Budi, R., Sos, S., Si, M., Cipta, H., \& oleh Percetakan, D. (2010). Pengantar IImu Komunikasi. Makassar. Kretakupa Print.

Christina Ariadne Sekar Sari (2017) Teknik Mengelola Produk \& Merek Jakarta PT. Gramedia Pustaka Utama

Dicky Sumarsono, C. H. A. (2015). Luar Biasa Bisnis Restoran di Indonesia: Semua Orang Bisa. Gramedia Pustaka Utama.

Diyanti, D. (2012). Strategi Marketing Public Relations Dalam Proses Rebranding.

Herlyana, E. (2014). Fenomena Coffee Shop Sebagai Gejala Gaya Hidup Baru Kaum Muda. Thaqafiyyat: Jurnal Bahasa, Peradaban dan Informasi Islam, 13(1), 187-204, dari file:///C:/Users/OS\%20Jatibarang/Downloads/4 3-44-1-PB\%20(1).pdf

Hidayati, H. A (2013). "Faktor-faktor yang Membentuk Komunikasi Word of Mouth dan Pengaruhnya terhadap Keputusan Pembelian (Studi pada Konsumen Ketan Legenda Batu)."

Hidayat, T. (2016). Pengaruh Marketing Public Relation Terhadap Loyalitas Pelanggan Pada PT. Jalur Nugraha Ekakurir (JNE) Bandung. Jurnal Ekonomi, Bisnis \& Entrepreneurship, 9(2), 102-115.

Indriyati, S. (2018). Strategi Rebranding Rumah Makan Chili Chicken Fruitly Menjadi Mr. Cobek Bulan Januari-Juli Tahun 2018 (Doctoral Dissertation, Fakultas IImu Sosial Dan IImu Politik UniversitasMuhammadiyah Yogyakarta).

Isyana, R. R. (2015). Strategi Pemasaran Melalui Rebranding (Studi Kasus Rebranding Piring Putih menjadi Redberries Food and Folks dalam Meningkatkan Penjualan). Universitas Islam Negeri Sunan Kalijaga Yogyakarta.

Izharuddin, M. (2016). Proses Rebranding Pada Plasa Marina Menggunakan Complex Processes Model

Kencana, M. (2018). Industri Makanan dan Minuman Bakal Tumbuh 10 Persen. Diakses dari Blog https://www.liputan6.com/bisnis/read/ 3243577/2018-industri-makanan-danminuman-bakal-tumbuh-10-persen

Kotler, Philip dan Gary Armstrong. 2008. Prinsipprinsip pemasaran. Edisi 12 jilid 1. Jakarta: Erlangga.

Kotler, Philip dan Kevin Lane Keller. (2008). Manajemen Pemasaran, jilid 1. Jakarta: Erlangga.

Kurniasari, A., Lestari, P., dan Isbandi. (2008). Strategi Marketing Public Relations PT. Telkom Kancatel Pati Dalam Program "Flexi Door to Door" dan "Speedy Go TO School" Untuk Membangun Brand Awareness dan Brand Knowledge di Wilayah Pati, 6(3), 231.

Lomax, W. dan Mandor, M. (2006). Corporate Rebranding : From Normative Models To Knowledge Management in Brand Management. Vol(14)

Marista, D. (2014). Corporate Rebranding melalui Promositional Tools (Studi Kasus pada Waralaba PT. Coffee Toffee Indonesia)

Muzellec, Laurent and Lambkin, Mary 2006. Corporate Rebranding : Destroying, Transferiring or Creating Brand Equity.

Papasolomou, I., Thrassou, A., Vrontis, D., \& Sabova, M. (2014). Marketing Public Relations: A consumer-focused strategic perspective. Journal of Customer Behaviour, 13(1), 7. Diakses dari Blog https://www.researchgate.ne t/publication/263108040_Marketing_Public_Rel ations_A_Consumerfocused_Strategic_Persp ective

Rangkuti, F. (2002). Teknik Mengelola Brand Equity dan Strategi Pengembangan Merek. Jakarta: Gramedia Pustaka Utama.

Rangkuti, F. (2013). Strategi promosi yang kreatif dan analisis kasus. Gramedia Pustaka Utama.

Ruslan, Rosady. (2017). Metode Penelitian: Public Relations \& Komunikasi. Jakarta: Rajawali Pers.

Rusmin P., Unde A. A., dan lqbal, S. (2015). Analisis Peran Public Relations (PR) Dalam Penanganan Opini dan Sikap Komunitas Sekitar, Terhadap Program Corporate Social Responsibility (CSR) PT. Energy Sengkang di Kabupaten Wajo. 4(4), 3.

Q2 2017 Badan Pusat Statistik (BPS) Report, 12. Diperoleh dari website https://www.slideshare. 
net/trecool/q2-2017-badan-pusat-statistik-bpsreport

Salmiyah, D. (2017). Marketing Public RelationsDiantara Penjualan dan Pencitraan. Yogyakarta : Deepublish

Sari, A. A. (2017). Dasar-dasar Public Relations Teori dan Praktik. Deepublish.

Solika, G. D. (2017). Pengaruh Rebranding Logo Toko Buku Gramedia Dan Tingkat Kepercayaan Konsumen Terhadap Citra Merek (Studi kasus di Toko Buku Gramedia Pandanaran)

Sujarweni, V. W. (2014). Metode Penelitian: Lengkap, Praktis, dan Mudah Dipahami. Yogyakarta: Pustakabarupress.

Suparno, Ludwig. 2011. Aspek IImu Komunikasi dalam Marketing Public Relations. Jakarta: PT Indeks.
Sutisna, (2001). Perilaku Konsumen dan Komunikasi Pemasaran. PT. Remaja Rosdakarya Bandung

Torsina, M. (2013). Formula Sukses Dalam Bisnis Restoran. Bhuana IImu Populer.

Warunk Upnormal Menu dan Sejarahnya (2015, September). Diperoleh pada 15 Agustus 2018 dari https://www.indonesiacayo.com/2018/03/w arunk-upnormal-menu-dan-sejarahnya.html

Wasesa, S.A. (2005). Strategi Public Relations. Jakarta: PT Gramedia Pustaka Utama. 